\title{
Distribution, Incidence and Severity of Maize Lethal Necrosis Disease in Major Maize Growing Agro-ecological Zones of Uganda
}

\author{
Barnabas Mudde ${ }^{1,2}$, Florence M'mogi Olubayo ${ }^{2}$, Douglas Watuku Miano², Godfrey Asea ${ }^{3}$, Dora C. Kilalo², \\ Andrew Kiggundu ${ }^{4}$, Daniel K. Bomet ${ }^{3} \&$ John Adriko $^{4}$ \\ ${ }^{1}$ Bulindi Zonal Agricultural Research and Development Institute, Hoima, Uganda \\ ${ }^{2}$ Department of Plant Science and Crop Protection, Faculty of Agriculture, College of Agriculture and Veterinary \\ Sciences, University of Nairobi, Nairobi, Kenya \\ ${ }^{3}$ National Crops Resources Research Institute, Namulonge, Kampala, Uganda \\ ${ }^{4}$ National Agricultural Research Laboratories, Kawanda, Kampala, Uganda \\ Correspondence: Barnabas Mudde, Bulindi Zonal Agricultural Research and Development Institute, P.O. Box \\ 101, Hoima, Uganda. Tel: 256-782-605-939. E-mail: bmudde2008@gmail.com
}

Received: February 27, $2018 \quad$ Accepted: April 6, $2018 \quad$ Online Published: May 15, 2018

doi:10.5539/jas.v10n6p72 URL: https://doi.org/10.5539/jas.v10n6p72

\begin{abstract}
The distribution, incidence and severity of maize lethal necrosis (MLN) disease in major maize growing agro-ecological zones (AEZ) of Uganda was determined following field surveys carried out in 16 major maize growing districts from 5 AEZ over three consecutive seasons. A total of 604 maize fields were visited and MLN disease status visually assessed and 3,624 maize leaf samples collected for identification and confirmation of the MLN causal viruses by Double antibody sandwich enzyme-linked immunosorbent assay (DAS-ELISA) and Reverse Transcription Polymerase Chain Reaction (RT-PCR). MLN disease was not widely distributed at an epidemic proportion, with only $36(5 \%)$ of the 604 farms surveyed over three seasons confirmed to have the disease. The MLN incidence and severity was significantly $(\mathrm{P}<0.05)$ higher in the Eastern AEZ during the three seasons. The main MLN-causing viruses detected using DAS-ELISA were Maize chlorotic mottle virus (MCMV) and Sugarcane mosaic virus (SCMV). MCMV was the most prevalent MLN causing virus driving the epidemic in Uganda. The three major districts where MLN disease has been found in all three seasons surveyed are Bulambuli, Tororo and Busia which are hotspots for MLN disease. Strategies to control spread of MLN disease should focus on high risk AEZs and hotspot districts.
\end{abstract}

Keywords: maize lethal necrosis disease, distribution, incidence, severity, Uganda, maize

\section{Introduction}

Maize (Zea mays L.) is a dietary staple and significant cash crop throughout the tropical world; serving as a food security crop for more than 70 million people in Sub Saharan Africa (Melinda et al., 2013). Uganda is the eighth largest maize producing country in Africa with 2,748,000 tonnes produced in 2013 (FAOSTAT, 2015). Production of maize in Uganda is greatly constrained by various biotic and abiotic production constraints. However, since 2012, the major threat to maize production in Uganda is the maize lethal necrosis disease (MLN) disease (Asea, 2013).

MLN is a viral disease caused by the double infection of maize plants with Maize chlorotic mottle virus (MCMV) (Tombusviridae: Machlomovirus) and any of the cereal viruses in the Potyviridae group, such as Sugarcane mosaic virus (SCMV), Maize dwarf mosaic virus (MDMV) or Wheat streak mosaic virus (WSMV) (Goldberg \& Brakke, 1987; Scheets, 1998). Under field conditions, the MLN-causing viruses are known to be transmitted from plant to plant by several insect vectors (Jiang et al., 1992; Cabanas, 2013; Ford et al., 2004) with alternative host plants in maize fields acting as sources of the MLN-causing viruses spread to maize (Nelson et al., 2011).

MLN was first identified in USA in 1976 (Niblett \& Claflin, 1978). It is an emergent virus disease in Africa that has become a major maize health constraint in the continent. In Africa, MLN was first reported in September 2011 in Kenya (Wangai et al., 2012). Since then, this notorious disease has spread to all major maize growing zones of the East and Central Africa including Rwanda (Adams et al., 2014), Democratic Republic of Congo (Lukanda et al., 2014), Tanzania (Kitenge, 2012) and Uganda (Asea, 2013; IPPC, 2014). 
MLN outbreaks causing variable yield losses have been reported to be as high as 90\% in the USA (Niblett \& Claflin, 1978; Uyemoto et al., 1980) and 30-100\% in Kenya (Wangai et al., 2012; Adams et al., 2012). In Kenya, the disease caused a total loss in maize valued at US\$ 67 M in 2012 (Prasanna, 2014). Surveys in eastern Uganda reported MLN infection in up to 30\% of the fields (Asea, 2013). It is most likely that the disease was present in the country for a number of years and was being confused with nitrogen deficiency. Development and implementation of integrated disease management systems against any disease in a geographical area is guided by precise and accurate information on the disease and factors that influence its development. However, because no quantifiable information is readily available on the distribution, incidence and severity of the MLN disease or MLN-causing viruses in major maize growing AEZ of Uganda, it has been difficult to develop an appropriate Integrated Disease Management System for the disease. When established, such information can indicate large scale risk factors associated with high MLN disease risk in Uganda, help in identification of maize growing areas with low or no occurrence of MLN where maize cultivation can be intensified and identify MLN hotspots that can be used as germplasm screening sites for maize breeding programs.

\section{Material and Methods}

\subsection{Field Survey Areas}

Three consecutive surveys were conducted between 2014 and 2015, that is, during the first season and second seasons of 2014 and first season of 2015 to assess changes in distribution, incidence and severity of maize lethal necrosis disease in major maize growing agro-ecological zones of Uganda. The study covered 16 major maize growing districts from 5 AEZ of Uganda according to the National Agricultural Research Organization (NARO, 1999) classified on the basis of distinct vegetation type, elevation and climatic conditions. The Eastern Agro-ecological Zone (EAZ) covered the districts of Tororo and Bukedea and is characterized by an annual average rainfall of $1197 \mathrm{~mm}$ with temperature ranges from 15-32.5 ${ }^{\circ} \mathrm{C}$. The Lake Albert Crescent Agro-ecological Zone (LACZ) covered the districts of Hoima, Masindi, Kibaale and Kiryandongo and is characterized by an annual average rainfall of $1259 \mathrm{~mm}$ with temperature ranging from $17.5-32.5{ }^{\circ} \mathrm{C}$. The South Eastern Agro-ecological Zone (SEAZ) covered the districts of Iganga, Busia and Bugiri with average annual rainfall ranging from $1215-1328 \mathrm{~mm}$ and temperature ranging from 15 to $32.5{ }^{\circ} \mathrm{C}$. The Eastern Highlands Agro-ecological Zone (EHAZ) covered the districts of Mbale, Bulambuli, Sironko, Kween and Kapchorwa with average annual rainfall more than $1400 \mathrm{~mm}$ and temperature ranging from 7.5 to $27.5^{\circ} \mathrm{C}$. The Western Highlands Agro-ecological Zone (WHAZ) covered the districts of Kasese and Kabarole with average annual rainfall of $1270 \mathrm{~mm}$ and temperature ranging from 15 to $30^{\circ} \mathrm{C}$.

\subsection{Sampling for MLN and MLN Causing Viruses}

In each sampling domain (district), at least 10 farmer fields and each farm at least $5 \mathrm{~km}$ from each other were assessed for symptoms of MLN and MLN-causing viruses namely Sugarcane mosaic virus (SCMV), Maize chlorotic mottle virus (MCMV), Maize dwarf mosaic virus (MDMV), and Wheat streak mosaic virus (WSMV). In first season of 2014, a total 171 maize farmers' fields were assessed, followed by 187 fields in second season of 2014, and in first season of 2015, 246 fields were assessed from 16 major maize growing districts in five agro-ecological zones of Uganda. Fields were selected at regular intervals along major and feeder roads traversing the sampling area. One to three (1-3) months old maize crops were assessed for foliar symptoms. In each maize field, scoring for MLN and MLN-causing virus symptoms was done on 20 maize plants. MLN disease assessment was made along the two diagonals (in an " $\mathrm{X}$ " pattern) of the field. This was done to obtain a better field representation. One maize leaf per plant from 3 maize plants showing typical symptoms of maize lethal necrosis disease or MLN-causing viruses and one maize leaf per maize plant from 3 maize plants not showing symptoms of maize lethal necrosis disease were picked per field. Using a clean sheet of tissue paper, the leaf to be sampled was enclosed and a 5-6 cm segment cut off using a bleach cleaned scissor. The single collected leaf sample was placed into a paper bag perforated with air holes and transferred to a labelled sample bag. A total of 3,624 maize leaf samples were collected from 16 districts.

\subsection{Determination of MLN Severity Incidence and Associated Factors}

In order to determine MLN disease incidence, data on disease incidence expressed as visual estimate of percentage coverage of maize plants infested was calculated according to Biswanath et al. (2013) formula: Where disease incidence (\%) is equal to the total number of infected plants as a percentage of the total number of plants in the row assessed. In order to determine disease severity, data on disease severity was assessed using a 1 to 5 scale by Biswanath et al. (2013), so that $1=$ no MLN symptoms, 2 = fine chlorotic streaks on lower leaves, $3=$ chlorotic mottling throughout plant, $4=$ excessive chlorotic mottling and dead heart and $5=$ complete plant necrosis. 
Distribution of the MLN was assessed through recording the altitudes, longitudes and latitudes for each sampled field using the GPS handset, Geko ${ }^{\circledR} 301$ Personal Navigator (Garmin International Inc., Olathe, Kansas, USA). The collected data was used to generate a map of sampled points by interpolating the surface from GPS points and the associated field incidence and severity data using the inverse distance, from which, mean values were calculated for all factors measured for each farmer field and district using ARC-VIEW 3.3 ${ }^{\circledR}$. The maps generated showed the distribution of MLN and MLN-causing viruses confirmed present.

\subsection{Serological Detection of Maize Lethal Necrosis Causing Viruses}

Double antibody sandwich enzyme-linked immunosorbent assay (DAS-ELISA) according to the general protocol by Clark \& Adams, 1977) with slight modifications was used to test for the presence of MLN causing viruses SCMV, MCMV, MDMV and WSMV in leaf samples collected from 16 major maize growing districts in five agro-ecological zones of Uganda. The antisera were purchased from Agdia ${ }^{\circledR}$ USA. The polyclonal antibodies used included anti-wheat streak mosaic virus, anti-sugarcane mosaic virus, anti-maize chlorotic mottle virus and anti-maize dwarf mosaic virus. All buffers were prepared according to the manufacturers specifications. Fresh maize leaf samples were crashed 1:20 (w/v) in extraction buffer using a motor and pestle. DAS-ELISA plates were prepared by adding $200 \mu \mathrm{l}$ coating antibody for each specific MLN causing virus into each well of microtitre plate (dilution 1:200 v/v of antibody: buffer) followed by 2 hours of incubation at $37{ }^{\circ} \mathrm{C}$. Plates were thereafter washed three times in PBS-T (Phosphate Buffered Saline-Tween $20 \mathrm{pH}$ 7.4) and dried on blotting paper. For each MLN specific virus, $200 \mu 1$ of the test sample extract were added into each well in duplicates and incubated at $4{ }^{\circ} \mathrm{C}$ overnight. Plates were again washed three times, blotted on blotting paper and $200 \mu 1$ enzyme conjugate diluted in ECL buffer 1:200 (v/v) added to each well. Plates were thereafter incubated at $37^{\circ} \mathrm{C}$ for 3 hours and washed three times. $200 \mu \mathrm{l}$ freshly prepared substrate $(1 \mathrm{mg} / \mathrm{ml}$ p-nitrophenyl-phosphate in substrate buffer) was added to each well, incubated at $37^{\circ} \mathrm{C}$ for 60 minutes. In the microtitre plates, positive and negative control tests were included. The positive controls were purchased from Agdia ${ }^{\mathbb{B}}$ (USA) together with the antibodies. Plates were then assessed visually for colour change and absorbance measured at $405 \mathrm{~nm}$ wavelength using a BIO-RAD ${ }^{\circledR}$ microtitre plate reader Model 680 (BIO-RAD Laboratories, Hercules, California, USA). All samples were assayed in duplicate and the results judged to be positive if the absorbance was greater than or equal to twice the average reading of the negative (healthy) controls.

\subsection{Reverse Transcription Polymerase Chain Reaction (RT-PCR) Virus Confirmation}

A Reverse Transcription Polymerase Chain Reaction protocol was used to confirm the presence of MLN causing viruses that were associated with MLN disease symptoms, following detection with ELISA.

\subsubsection{Ribonucleic Acid (RNA) Extraction}

Total RNA was extracted from fresh maize leaf samples kept at $-80{ }^{\circ} \mathrm{C}$ by using $\mathrm{AccuZol}{ }^{\mathrm{TM}} \mathrm{RNA}$ extraction reagent (Bioneer Inc, South Korea) according to the manufacturer's instructions as described. A maize leaf weighing $100 \mathrm{mg}$ tissue frozen in liquid nitrogen was macerated in $1 \mathrm{ml}$ of $A c c u Z o l^{\mathrm{TM}}$ using an autoclaved mortar and pestle. $200 \mu \mathrm{l}$ of chloroform was added and the mixture shaken for 15 seconds and incubated on ice for 5 minutes. The mixture was then centrifuged at $12,000 \mathrm{rpm}$ for 15 minutes at $4{ }^{\circ} \mathrm{C}$ and $450 \mu 1$ of the upper aqueous layer transferred to a fresh $1.5 \mathrm{ml}$ Eppendorf tube. An equal volume of Isopropyl alcohol was added, the solution mixed by inverting the tube 5 times and incubated at $-20^{\circ} \mathrm{C}$ for 10 minutes. The solution was then centrifuged at $12,000 \mathrm{rpm}$ for 10 minutes at $4{ }^{\circ} \mathrm{C}$, the supernatant carefully removed and $1 \mathrm{ml}$ of $80 \%$ ethanol added. The solution was centrifuged at $12,000 \mathrm{rpm}$ for 5 minutes at $4{ }^{\circ} \mathrm{C}$ to pellet the RNA. The supernatant was carefully removed. The RNA formed that remained in the tube was dissolved in $100 \mu 1$ of RNAase free water and stored at $-80{ }^{\circ} \mathrm{C}$.

\subsubsection{Complementary Deoxyribonucleic Acid (cDNA) Synthesis}

Complementary DNAs (cDNAs) were synthesized from total RNA extracts using the AccuPower ${ }^{\mathbb{R}}$ Reverse Transcription Polymerase Chain Reaction (RT-PCR) PreMix kit (Bioneer Corporation, Korea) following manufacturer's instructions. $2.5 \mu \mathrm{l}$ of total RNA was mixed with $1 \mu \mathrm{l}$ of reverse primer of MCMV or SCMV in a sterile PCR tube and the mixture incubated at $70{ }^{\circ} \mathrm{C}$ for 5 minutes and placed on ice to cool for 3 minutes. The cooled incubated mixture was then transferred into an AccuPower ${ }^{\circledR}$ PCR PreMix tube. The reaction volume was then topped with $16.5 \mu 1$ of diethylpyrocarbonate (DEPC) water to make a $20 \mu 1$ reaction. The mixture was incubated at $42{ }^{\circ} \mathrm{C}$ for 1 hour for cDNA synthesis and $94{ }^{\circ} \mathrm{C}$ for 5 minutes followed by holding at $8{ }^{\circ} \mathrm{C}$.

\subsubsection{PCR Amplification, Electrophoresis, Staining and Visualization}

The cDNAs were diluted in two folds and amplified using polymerase chain reaction (PCR) Thermocycler (BIONEER Model Name: Mygenie 96, Serial Number 96-1101016). The PCR reaction mixture consisted of $2 \mu 1$ 
of synthesized complementary DNA (cDNA) product, $0.5 \mu 1$ of reverse primer for MLN viruses (MCMV or SCMV), $0.5 \mu \mathrm{l}$ of forward primer for individual MLN causing viruses and $17 \mu 1$ of nuclease free water in $0.2 \mathrm{ml}$, flat cap PCR tubes containing AccuPower ${ }^{\mathbb{B}}$ PCR (Bioneer, Korea) master mix made of DNA Polymerase, Deoxynucleotide triphosphates (dNTPs), a tracking dye and reaction buffer in a premixed format. The reaction was set in a Thermocycler using the following thermal cycling programme: 35 cycles, of $94{ }^{\circ} \mathrm{C}$ for 5 minutes, 50 to $60{ }^{\circ} \mathrm{C}$ for 45 seconds and $72{ }^{\circ} \mathrm{C}$ for 1 minute; and a final extension at $72{ }^{\circ} \mathrm{C}$ for 3 minutes and held at $8{ }^{\circ} \mathrm{C}$. Annealing temperatures were dependent on primers used for detection of individual MLN causing viruses. The RT-PCR product was electrophoresed on $1.5 \%$ agarose gels for 45 minutes at $120 \mathrm{~V}$ and current of $400 \mathrm{~mA}$ in TAE agarose gel, and then visualized under UV light so as to determine successful amplification of the desired fragment. Samples that showed the expected band sizes of 550bp for MCMV and $900 \mathrm{bp}$ for SCMV were considered positive for MCMV and SCMV, respectively in PCR. Virus identities were verified with MCMV primers (2681F: 5'-ATGAGAGCAGTTGGGGAATGCG-3' and 3226R: 5'-CGAATCTACACACACACACTC CAGC) and SCMV primers 8679F: (5'-35 GCAATGTCGAAGAAAATGCG-3') and 9595R: (5'-GTCTCTCAC CAAGAGACTCGCAGC-3') according to Wangai et al. (2012).

\subsection{Data Analysis}

General analysis of variance (ANOVA) was used for detection of significance of the effects of type of agroecological condition, type of maize variety, cultivation environment and elevation on the observed MLN disease severities and incidence using GenStat 15th edition statistical software (VSN International, UK) and XLSTAT version 2015 (Copyright Addinsoft 1995-2015). Separation of means was done using Least Significant Difference (LSD) at $\mathrm{p}<0.05$. The correlation coefficient between disease prevalence, incidence and severity was determined. Weather data were obtained from http://me.awhere.com. Rainfall, temperature and relative humidity were considered to be the most important parameters for MLN disease occurrence and therefore used to establish the relationship for the disease progress against weather variation.

\section{Results}

3.1 Maize Lethal Necrosis Disease Symptom Incidence and Severity in Major Maize Growing Agro-ecological Zones in Uganda from 2014 A to 2015 A

During the first season of 2014, there were significant $(\mathrm{P}<0.05)$ differences in MLN symptom incidences and severities across different agro-ecological zones (Table 1). The disease was detected in four of the five major maize growing agro-ecological zones surveyed (Table 1). MLN disease symptom incidence and severity was highest in Eastern Agro-ecological zone (14\% and 1.48) followed by Eastern Highland Agro-ecological zone (12.07\% and 1.42), South Eastern Agro-ecological zone (6.17\% and 1.2). In both Lake Albert Crescent Agro-ecological Zone and Western Highland Agro-ecological Zones no MLN symptoms were observed during the first season 2014. Incidence and severity of MLN disease symptoms recorded during second season 2014 was highest in Eastern Agro-ecological zone (9.4\% and 1.33); followed by Eastern Highland Agro-ecological zone (4.08\% and 1.14) and South Eastern Agro-ecological zone (4.05\% and 1.13). In both Lake Albert Crescent Agro-ecological Zone and Western Highland Agro-ecological Zones no MLN symptoms were also observed during the second season 2014. However, in the first season of 2015, there were significant $(\mathrm{P}<0.05)$ differences in MLN disease symptom incidence across different agro-ecological zones. MLN disease symptom incidence and severity remained highest in Eastern Agro-ecological zone (18.07\% and 1.68) and significantly dropped in the South Eastern Agro-ecological zone (3.97\% and 1.13), Western Highland Agro-ecological Zones (3.64\% and 1.14) and Eastern Highland Agro-ecological zone (1.67 and 1.06). Unlike in the previous two seasons, only Lake Albert Crescent Agro-ecological Zone had no MLN disease symptoms observed during the first season 2015. 
Table 1. Severity and incidence of MLN symptoms in major maize growing agro-ecological zones of Uganda during first season 2014, second season 2014 and first season 2015

\begin{tabular}{|c|c|c|c|c|c|c|}
\hline \multirow[b]{2}{*}{ Agro-ecological zone } & \multicolumn{2}{|c|}{ First season 2014} & \multicolumn{2}{|c|}{ Second season 2014} & \multicolumn{2}{|c|}{ First season 2015} \\
\hline & $\begin{array}{l}\text { MLN } \\
\text { incidence } \\
(\%)\end{array}$ & $\begin{array}{l}\text { MLN } \\
\text { severity } \\
(1-5)\end{array}$ & $\begin{array}{l}\text { MLN } \\
\text { incidence } \\
(\%)\end{array}$ & $\begin{array}{l}\text { MLN } \\
\text { severity } \\
(1-5)\end{array}$ & $\begin{array}{l}\text { MLN } \\
\text { incidence } \\
(\%)\end{array}$ & $\begin{array}{l}\text { MLN } \\
\text { severity } \\
(1-5)\end{array}$ \\
\hline Eastern Agro-ecological zone & 14.00 & 1.48 & 9.40 & 1.33 & 18.07 & 1.68 \\
\hline Eastern Highland Agro-ecological zone & 12.07 & 1.42 & 4.08 & 1.14 & 1.67 & 1.06 \\
\hline South Eastern Agro-ecological zone & 6.17 & 1.2 & 4.05 & 1.13 & 3.97 & 1.13 \\
\hline Lake Albert Crescent Agro-ecological zone & 0.00 & 1.00 & 0.00 & 1.00 & 0.00 & 1.00 \\
\hline Western Highlands Agro-ecological Zone & 0.00 & 1.00 & 0.00 & 1.00 & 3.64 & 1.14 \\
\hline $\mathrm{LSD}_{0.05}$ & 11.03 & 0.38 & 7.39 & 0.25 & 6.8 & 0.25 \\
\hline $\operatorname{Pr}>F$ & $0.035 *$ & $0.034 *$ & $0.181 \mathrm{~ns}$ & $0.166 \mathrm{~ns}$ & $<0.001 * * *$ & $<0.001^{* * *}$ \\
\hline
\end{tabular}

Note. * Significant at $\mathrm{P}<0.05 ; * *$ Significant at $\mathrm{P}<0.01 ; * * *$ Significant at $\mathrm{P}<0.001 ; \mathrm{ns}=$ non-significant at $\mathrm{P}<$ 0.05 .

3.2 Distribution of MLN in Surveyed Districts from Major Maize Growing Agro-ecological Zones of Uganda During First Season 2014, Second Season 2014 and First Season 2015

Characteristic symptoms of MLN disease were observed in a total of 36 farmers' fields surveyed over three seasons. The symptoms observed were fine chlorotic streaks on older leaves, chlorotic mottling through out the plant and excessive mottling (Figure 1).
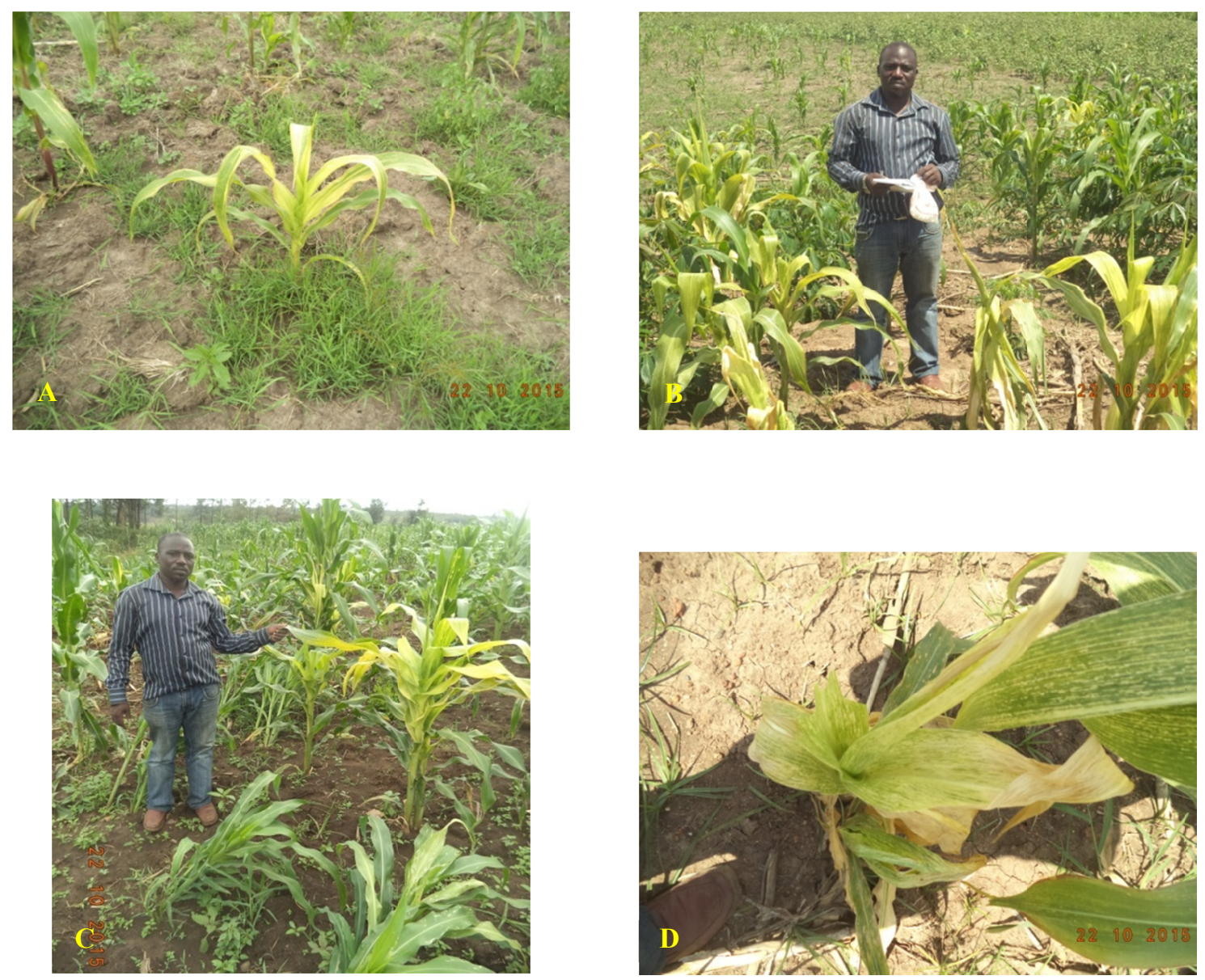

Figure 1. MLN disease symptoms as observed in fields surveyed in Uganda. A and B: fine chlorotic streaks on older leaves. C. Chlorotic mottling throughout entire plant. D: Excessive chlorotic mottling 
Distribution maps produced indicated that MLN was not widely distributed in Uganda with only 36 (5\%) of the 604 farms surveyed from 16 districts over three seasons confirmed by visual assessment to have the MLN disease (Figure 2). The disease was prevalent in districts found in Eastern agroecological zone of Uganda during the three consecutive seasons. During the first season of 2014, Mbale district registered the highest incidence and severity of MLN disease (31.7\% and 2.04) followed by Bukedea (18.7\% and 1.65), Bulambuli (11.3\% and 1.45), Tororo (11.24\% and 1.38), Bugiri (10\% and 1.3), Sironko (9.5\% and 1.35) and Busia (8.5\% and 1.3). The other districts surveyed did not have any MLND symptoms observed. The incidence and severity of MLN recorded during the second season of 2014, was highest in Busia (15.8\% and 1.50) followed by Tororo (15.67\% and 1.55), Mbale (10.87\% and 1.37) and Bulambuli (6.62\% and 1.23). During first season 2015, Bukedea district registered the highest incidence and severity of MLN (31.0\% and 2.10) followed by Tororo (15.67\% and 1.48), Busia (13.17\% and 1.42), Bulambuli (7.75\% and 1.28), Kasese (6.67\% and 1.25), and Iganga (3.81\% and 1.14$)$. The three major districts where the disease has been found in all the three seasons surveyed are Bulambuli, Tororo and Busia which are now confirmed hotspots for the disease and can be used to screen tolerant varieties in Uganda.
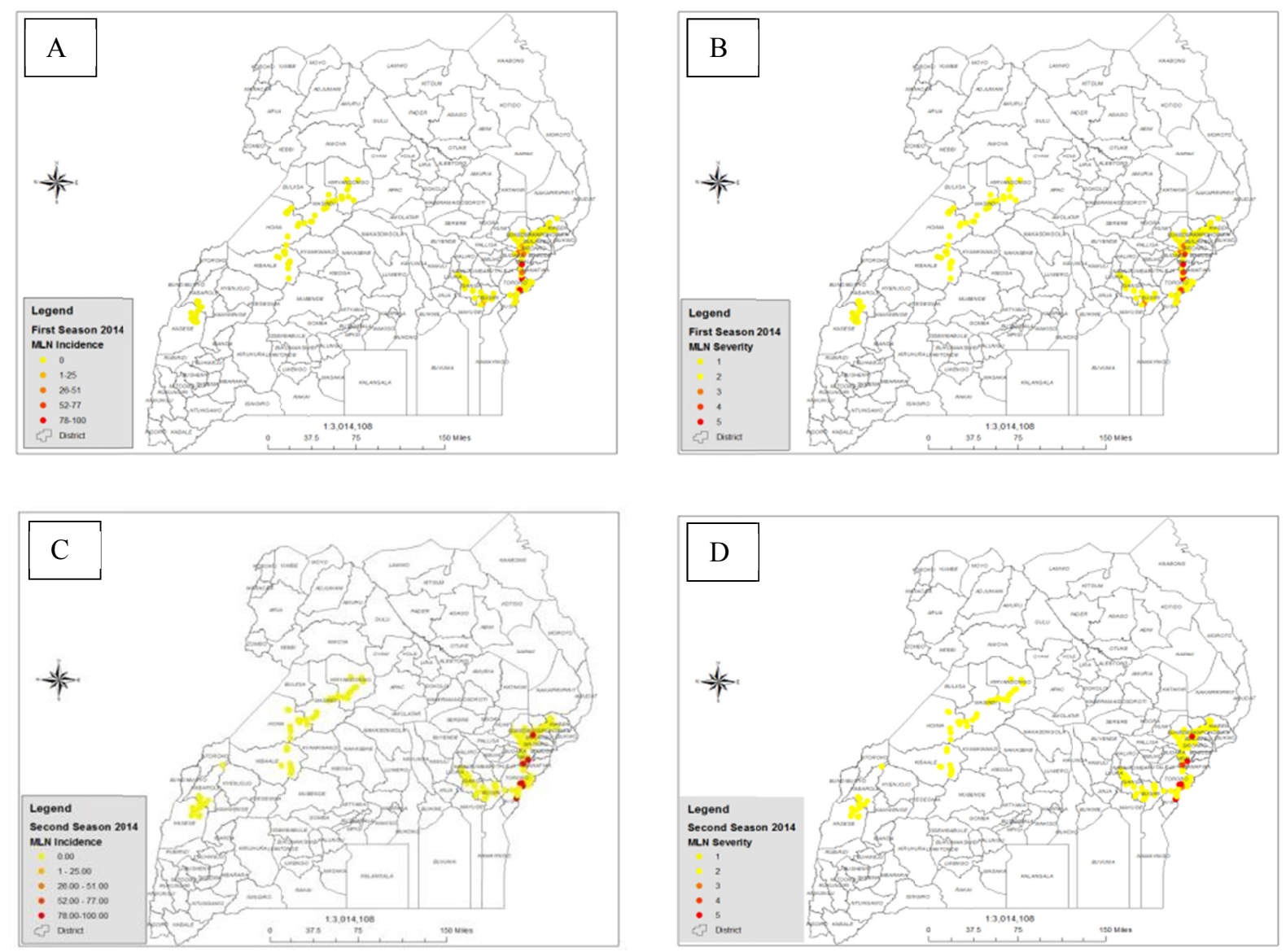

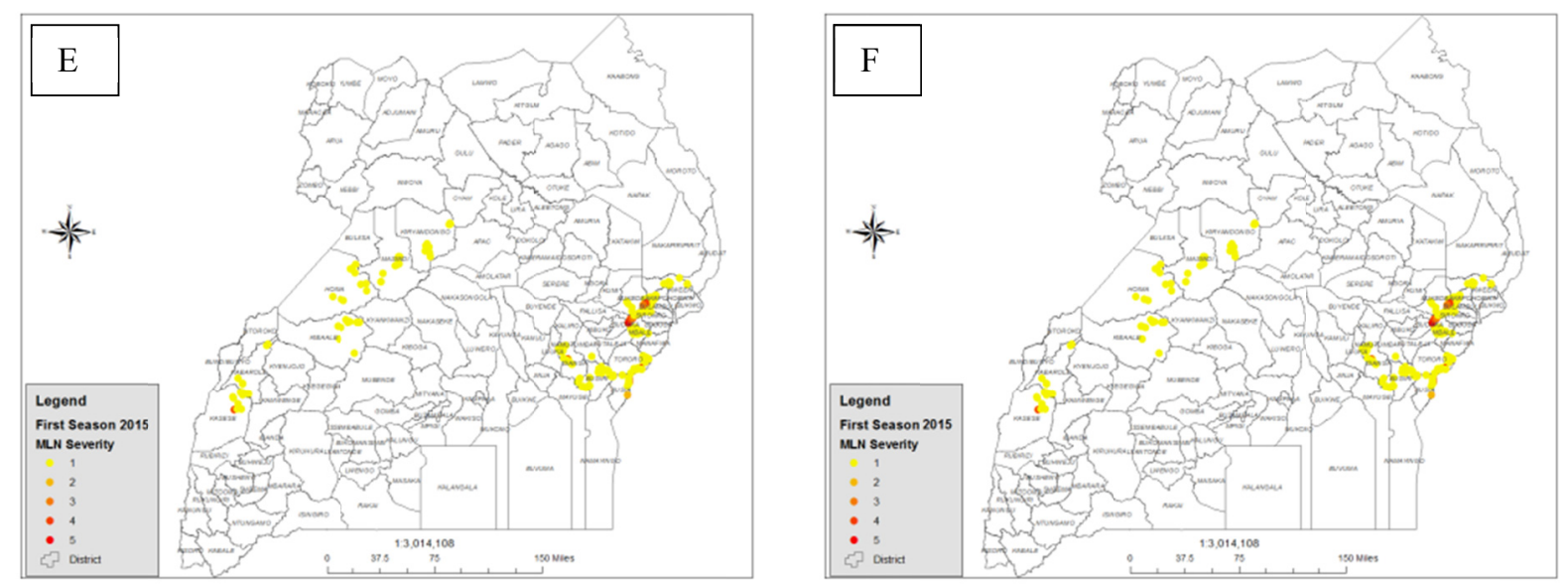

Figure 2. Distribution of farms showing incidence and severity of MLN in major maize growing districts of Uganda during first season 2014, second season 2014 and first season 2015

Note. A $=$ MLN incidence in 2014A, B = MLN severity in 2014A, C = MLN incidence in 2014B, D = MLN severity in 2014B, $\mathrm{E}=$ MLN incidence in 2015A, $\mathrm{F}=$ MLN severity in 2015A.

\subsection{MLN Disease Incidence and Severity in the Most Frequently Grown Cultivars of Maize in Uganda Over 3 Cropping Seasons 2014A, 2014B and 2015A}

A total of 15 different maize varieties were encountered during the survey. These included DK, Hybrid 614, Hybrid 624, Hybrid 6303, Kawanda Composite, Local, Longe 10H, Longe 2H, Longe 4, Longe 5, Longe 6, Longe $6 \mathrm{H}$, Longe $7 \mathrm{H}$, Longe $9 \mathrm{H}$. The predominant varieties differed between and sometimes within districts and in different seasons (Table 2). However, it should be noted that the same variety may be given different names in different areas and morphologically different varieties may bear similar names in different districts. Overall Longe 5 was the most widely grown variety grown in all the surveyed districts during all the seasons surveyed (Table 2). More than one variety was grown elsewhere and in some cases many varieties were even grown in the same field. The most frequently grown maize cultivars were susceptible to MLN. Longe 5 was the most widely grown maize cultivar and different commonly cultivated varieties recorded highest incidence and severities in the three seasons. During the first season 2014, the mean incidence and severity of MLN in the different varieties was 7.11 and 1.243 respectively. The highest MLN disease incidence and severity was in cultivar Longe $7 \mathrm{H}$ (31.67\% and 2.167). During the second season 2014, the mean incidence and severity of MLN in the different varieties was 3.43 and 1.117 respectively. The highest MLN disease incidence and severity was in cultivar Hybrid 513 (10.86\% and 1.429). During the first season 2015, the mean incidence and severity of MLN in the different varieties was 4.2 and 1.152 respectively. The highest MLND incidence and severity was in cultivar DK (38\% and 2.5). 
Table 2. MLN disease incidence and severity observed on the most frequently grown cultivars of maize in Uganda for 3 cropping seasons 2014A, 2014B and 2015A

\begin{tabular}{|c|c|c|c|c|c|c|c|}
\hline \multirow[b]{2}{*}{ Maize cultivar } & \multirow[b]{2}{*}{$\begin{array}{l}\text { Total number } \\
\text { of fields }\end{array}$} & \multicolumn{2}{|c|}{ First season 2014} & \multicolumn{2}{|c|}{ Second season 2014} & \multicolumn{2}{|c|}{ First season 2015} \\
\hline & & $\begin{array}{l}\text { MLN } \\
\text { incidence } \\
(\%)\end{array}$ & $\begin{array}{l}\text { MLN } \\
\text { severity } \\
(1-5 \text { scale })\end{array}$ & $\begin{array}{l}\text { MLN } \\
\text { incidence } \\
(\%)\end{array}$ & $\begin{array}{l}\text { MLN } \\
\text { severity } \\
(1-5 \text { scale })\end{array}$ & $\begin{array}{l}\text { MLN } \\
\text { incidence } \\
(\%)\end{array}$ & $\begin{array}{l}\text { MLN } \\
\text { severity } \\
(1-5 \text { scale })\end{array}$ \\
\hline DK & 7 & 0.0 & 1.0 & 0.0 & 1.0 & 38.0 & 2.5 \\
\hline Hybrid 513 & 20 & 13.6 & 1.5 & 10.9 & 1.4 & 0.0 & 1.0 \\
\hline Hybrid 614 & 36 & 0.0 & 1.0 & 6.3 & 1.2 & 0.0 & 1.0 \\
\hline Hybrid 624 & 5 & & & 0.0 & 1.0 & 0.0 & 1.0 \\
\hline Hybrid 6303 & 7 & & & 0.0 & 1.0 & 0.0 & 1.0 \\
\hline Kawanda Composite A & 35 & 0.0 & 1.0 & 0.0 & 1.0 & 0.0 & 1.0 \\
\hline Local & 58 & 0.0 & 1.0 & 0.0 & 1.0 & 3.9 & 1.2 \\
\hline Longe $10 \mathrm{H}$ & 90 & 8.7 & 1.2 & 6.9 & 1.2 & 3.5 & 1.1 \\
\hline Longe 4 & 55 & 7.1 & 1.2 & 0.0 & 1.0 & 15.7 & 1.6 \\
\hline Longe 5 & 237 & 9.7 & 1.3 & 3.5 & 1.1 & 4.7 & 1.2 \\
\hline Longe 6 & 16 & 0.0 & 1.0 & 17.2 & 1.6 & 0.0 & 1.0 \\
\hline Longe $6 \mathrm{H}$ & 6 & & & 0.0 & 1.0 & 0.0 & 1.0 \\
\hline Longe $7 \mathrm{H}$ & 24 & 31.7 & 2.2 & 0.0 & 1.0 & 0.0 & 1.0 \\
\hline Longe $2 \mathrm{H}$ & 4 & 25.5 & 2.3 & 0.0 & 1.0 & & \\
\hline Longe 9H & 4 & & & & & 0.0 & 1.0 \\
\hline $\mathrm{LSD}_{0.05}$ & & 16.65 & 0.569 & 13.05 & 0.449 & 12.2 & 0.448 \\
\hline $\operatorname{Pr}>F$ & & 0.4 & 0.205 & 0.8 & 0.807 & 0.27 & 0.219 \\
\hline
\end{tabular}

\subsection{Effect of Weather Parameters and Altitude on Development of MLN Disease}

During the first season 2014, MLN disease development mainly occurred at maximum temperatures of 23.73$24.08{ }^{\circ} \mathrm{C}$, relative humidity of $63.22-66.26 \%$ and rainfall range of $126.62-418.94 \mathrm{~mm}$. During the second season 2014, MLN disease in maize was favoured by maximum temperatures of $22.72-24.08{ }^{\circ} \mathrm{C}$, relative humidity of $72.92-72.99 \%$ and rainfall range of 664.33-1723.01mm. During the first season 2015, MLN disease incidence in maize was favoured by maximum temperatures of $22.82-24.64{ }^{\circ} \mathrm{C}$, relative humidity of $65.70-71.52 \%$ and rainfall range of 138.60-361.20 mm.

During the first season 2014, results showed significant negative correlation coefficient $(\mathrm{P} \leq 0.05)$ between MLN disease incidence and altitude. Results also showed a significant $(\mathrm{P} \leq 0.05)$ positive correlation coefficient between MLN disease incidence and rainfall (Table 3). It was found that a decrease in altitude resulted in an increase in MLN disease but an increase in rainfall also resulted in an increase in MLN disease. During the second season 2014, results showed significant negative correlation coefficient $(P \leq 0.05)$ between MLN disease incidence and altitude. Results also showed a significant $(\mathrm{P} \leq 0.05)$ positive correlation coefficient between MLN disease incidence and rainfall. It was found that a decrease in altitude resulted in an increase in MLN disease but an increase in rainfall also resulted in an increase in MLN disease. During the first season 2015, results showed significant negative correlation coefficient $(\mathrm{P} \leq 0.05)$ between MLN disease incidence and altitude (Table 3). It was found that a decrease in altitude resulted in an increase in MLND. Over the three cropping seasons, results showed significant negative correlation coefficient $(P \leq 0.05)$ between MLN disease incidence and altitude coupled with a significant positive correlation coefficient $(\mathrm{P} \leq 0.05)$ between MLN disease incidence and rainfall. MLN disease incidence was favoured by maximum temperature range of $22.72-24.64{ }^{\circ} \mathrm{C}$, relative humidity range of $63.22-72.99 \%$ and a rainfall range of $126.62-1723.01 \mathrm{~mm}$. 
Table 3. Relationship between MLN disease incidence and environmental parameters during first season 2014

\begin{tabular}{|c|c|c|c|c|c|}
\hline District & $\begin{array}{l}\text { MLN } \\
\text { Incidence (\%) }\end{array}$ & $\begin{array}{l}\text { Altitude } \\
\text { (m.a.s.l)* }\end{array}$ & Mean Temp & $\begin{array}{l}\text { Accumulative } \\
\text { Precipitation }(\mathrm{mm})\end{array}$ & $\begin{array}{l}\text { Mean Relative } \\
\text { Humidity }\end{array}$ \\
\hline Mbale & 31.7 & 1203.2 & 24.1 & 205.4 & 66.0 \\
\hline Bukedea & 18.7 & 1120.5 & 24.5 & 128.8 & 63.2 \\
\hline Bulambuli & 11.3 & 1142.9 & 24.1 & 126.6 & 63.6 \\
\hline Tororo & 11.2 & 1213.5 & 23.9 & 282.1 & 65.5 \\
\hline Bugiri & 10.0 & 1138.1 & 24.2 & 264.7 & 66.1 \\
\hline Sironko & 9.5 & 1170.7 & 21.0 & 205.7 & 64.2 \\
\hline Busia & 8.5 & 1152.0 & 23.7 & 418.9 & 66.3 \\
\hline Kween & 0.0 & 1494.4 & 19.0 & 64.9 & 63.3 \\
\hline Kapchorwa & 0.0 & 1610.3 & 19.3 & 64.9 & 63.4 \\
\hline Iganga & 0.0 & 1127.5 & 24.2 & 228.5 & 65.8 \\
\hline Kabarole & 0.0 & 1304.0 & 21.9 & 184.3 & 70.1 \\
\hline Kibaale & 0.0 & 1166.3 & 23.6 & 141.9 & 65.1 \\
\hline Kasese & 0.0 & 1064.8 & 22.8 & 59.6 & 68.2 \\
\hline Hoima & 0.0 & 1092.9 & 23.9 & 135.0 & 63.0 \\
\hline Kiryandongo & 0.0 & 1081.9 & 24.7 & 155.3 & 61.0 \\
\hline Masindi & 0.0 & 1117.4 & 23.6 & 143.8 & 61.8 \\
\hline \multicolumn{2}{|c|}{ Pearson's Correlation ${ }^{\mathrm{a}}$} & 0.0 & 0.3 & 0.3 & 0.1 \\
\hline \multicolumn{2}{|l|}{$P$ value } & 0.001 & 0.209 (NS) & 0.008 & 0.796 (NS) \\
\hline
\end{tabular}

Note. $\mathrm{a}=$ correlation of MLN disease incidence with environmental parameters in corresponding column; NS $=$ Non significant at $\mathrm{P}<0.05$; source for weather data: http://me.awhere.com. * m.a.s.l. = Metres above mean sea level.

\subsection{Serological Identification of MLN Viruses and the Infection Rate in Surveyed Districts}

MLN Symptoms observed in the field on symptomatic plants were mainly fine chlorotic streaks on leaves and mild leaf mottling. In order to confirm that symptoms observed on maize were indeed due to MLN-causing viruses. Samples from a total of 604 farmer fields were tested. Based on DAS-ELISA results, MCMV was the only detected MLN causing virus from maize leaf samples during all the three seasons while Sugarcane mosaic virus was only detected during the first season 2015. The infection rate was the proportion of total fields assessed that had samples showing positive antibody reaction for the virus tested. Bukedea had the highest infection rate (20\%), followed by Busia (15.63\%), Tororo (15.09\%) and Mbale (13.21\%) districts (Table 4). 
Table 4. Serological identification of MLN viruses and the infection rate in surveyed districts from major maize growing agroecologies of Uganda over 3 consecutive seasons 2014A-2015A

\begin{tabular}{llllll}
\hline District & $\begin{array}{l}\text { Total number } \\
\text { of fields }\end{array}$ & $\begin{array}{l}\text { Number of fields with } \\
\text { samples having MCMV } \\
\text { positive antibody reaction }\end{array}$ & $\begin{array}{l}\text { MCMV } \\
\text { infection } \\
\text { rate (\%) }\end{array}$ & $\begin{array}{l}\text { Number of fields with } \\
\text { samples having SCMV } \\
\text { positive antibody reaction }\end{array}$ & $\begin{array}{l}\text { SCMV } \\
\text { infection } \\
\text { rate (\%) }\end{array}$ \\
\hline Bugiri & 53 & 2 & 3.77 & 0 & 0.00 \\
Bukedea & 30 & 6 & 20.00 & 0 & 0.00 \\
Bulambuli & 43 & 5 & 11.63 & 2 & 4.65 \\
Busia & 32 & 5 & 15.63 & 0 & 0.00 \\
Hoima & 30 & 0 & - & 0 & 0.00 \\
Iganga & 44 & 1 & 2.27 & 0 & 0.00 \\
Kabarole & 30 & 0 & - & 0 & 0.00 \\
Kapchorwa & 35 & 0 & - & 0 & 0.00 \\
Kasese & 34 & 1 & 2.94 & 0 & 0.00 \\
Kibaale & 30 & 0 & - & 0 & 0.00 \\
Kiryandongo & 30 & 0 & - & 0 & 0.00 \\
Kween & 32 & 0 & - & 0 & 0.00 \\
Masindi & 30 & 0 & - & 0 & 0.00 \\
Mbale & 53 & 7 & 13.21 & 1 & 1.89 \\
Sironko & 45 & 1 & 2.22 & 0 & 0.00 \\
Tororo & 53 & 8 & 15.09 & 6 & 11.32 \\
- Total & 604 & 36 & & 9 & \\
\hline
\end{tabular}

\subsection{Molecular Detection of MLN-Causing Viruses}

The samples that tested positive for MCMV and SCMV using DAS- ELISA were further tested using the designed primers MCMV primers (2681F: 5'-ATGAGAGCAGTTGGGGAATGCG and 3226R: 5'-CGAATC TACACACACACACTCCAGC) and SCMV primers 8679F: (5'-GCAATGTCGAAGAAAATGCG) and 9595R: (5'-GTCTCTCACCAAGAGACTCGCAGC) according to Wangai et al. (2012). Only the PCR products of expected sizes for MCMV of 550 bp was amplified as shown in Figure 3.

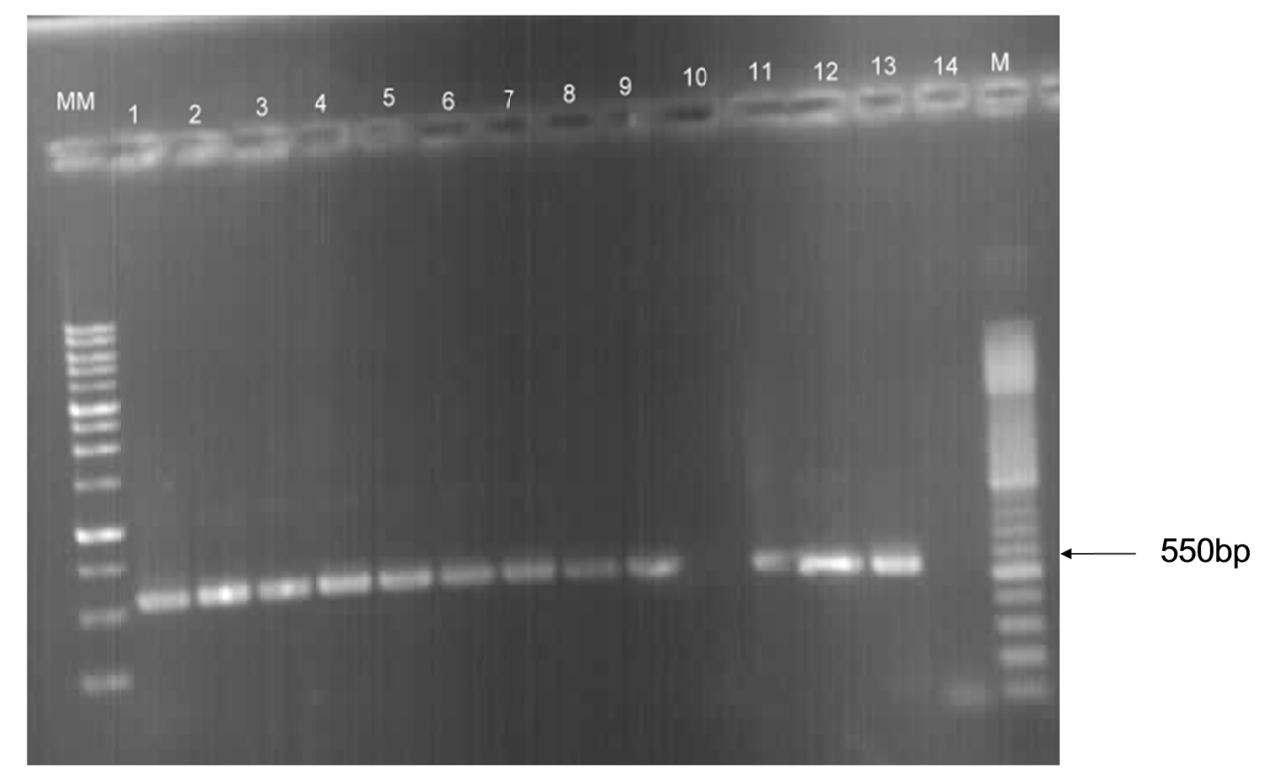

Figure 3. RT-PCR amplified products of MCMV obtained using primers MCMV2861F and MCMV3226R (550bp). Lane MM shows a 1kb DNA Ladder (Bioneer). Lane 1-9 positive samples from Bulambuli and Mbale districts. Lane 10 shows a negative sample from Mbale district. Lane 11-12. Positive samples from Tororo district. Lane 13. MCMV positive control from Agdia ${ }^{\circledR}$. Lane 14 Water as negative control. Lane M shows a 100bp DNA Ladder (Bioneer) 


\section{Discussion}

It was hypothesized that MLN differs in incidence, severity and distribution in different maize growing agroecological zones of Uganda. Differences in MLN disease incidences and severity among agroecological zones were indeed observed in this study and this supported our hypothesis. MLN incidence and severity was significantly $(\mathrm{P}<0.05)$ higher in the Eastern AEZ during the three seasons. The highest disease pressure of MLN in the Eastern Agro-ecological Zones comprising of the districts of Bukedea, Tororo and Busia could be attributed to their close proximity to western Kenya where the disease was first reported (Mahuku et al., 2015; IPPC, 2014; Asea, 2013; Kagoda et al., 2016). Lack of a seed certification scheme, recycling of seed and free movement of seed especially from neighboring countries that harbor the disease may have a role to play especially in eastern Uganda which borders western Kenya from which the disease was first reported on the African continent (Wangai et al., 2012). Due to the close proximity of eastern Uganda to western Kenya, there is need to emphasize on local quarantine to minimize pathogen spread and disease incidence to other unaffected agro-ecological zones in Uganda. The disease occurrence in Kasese district located in the Midwestern agroecological zone observed during the first season 2015, could be due to the location in the Mubuku Irrigation scheme where intensive maize seed multiplication is done by local and foreign seed companies which provided a source of elite maize varieties that could have been infected with the MLN-causing viruses. Therefore, the disease might have been indirectly introduced to farmer fields when farmers obtained seed from the scheme. MLN causing viruses notably MCMV, SCMV and MDMV have been confirmed to be seed borne although at very low levels of $0.04 \%$ (Jensen et al., 1991; Mikel et al., 1984). However, even extremely low rates of seed transmission such as those observed by these researchers have been reported to facilitate the introduction of viruses into new crop-production areas (Maule et al., 1996). More research about the role of seed transmission is needed. The absence of MLN in districts of the Lake Albert crescent agro-ecological zone including Kibaale, Masindi, Hoima and Kiryandongo districts is probably due to minimal movement of seed from the neighboring districts like Kasese or less intensive cultivation of maize in the Lake Albert Crescent Zone districts of Uganda. However, disease development in these districts could be just a matter of time. Considering the relatively high incidence and severity of infection observed in maize in the Eastern and Eastern highland Agro-ecological zones, these zones therefore deserve the highest priority for research and control. Thus, there is a need for an area-wide MLN disease management strategy for areas at higher MLN disease risk e.g. growers in regions at higher risk should apply strategies that reduce MLN disease build up in the fields such as controlling the insect vectors; timely weeding; fertilizer application and rouging of infected plants, while those in areas at lesser risk should apply strategies such as quarantine and planting MLN disease free seed to prevent spread of MLN disease to other areas.

The observed fine chlorotic streaks on leaves and mild leaf mottling foliar symptoms were characteristic of MLN causing virus, MCMV. Viruses belonging to the Tombusviridae and Potyviridae are known to cause mottling and mosaic symptoms on maize (Brunt et al., 1990). Serological assays confirmed mainly the presence of Maize Chlorotic mottle virus (MCMV), the key MLN causing virus driving the spread of the epidemic in Uganda. This is consistent with earlier results by Kagoda et al. (2016) who also confirmed the presence MCMV in samples collected in Eastern Uganda. A probable hypothesis is that MCMV alone is capable of causing the expression of MLN disease symptoms. This is in agreement with reports by Mahuku et al. (2015) who reported that MCMV alone is capable of leading to MLN disease development. The RT-PCR test done on total RNA extracted from farmers fields confirmed the presence of MLN-causing viruses notably MCMV from all samples that tested positive for MCMV using ELISA. However, samples that showed positive reaction to the Sugarcane mosaic virus (SCMV) using ELISA were not detected using RT-PCR probably due to the existence of new strains with differences in the capsid protein sequence from which the primers were designed. Similarly RT-PCR failed to detect SCMV from samples from Rwanda using primers designed for the Kenyan isolate of SCMV (Adams et al., 2014).

During the survey at least 15 maize varieties were observed to be frequently grown by farmers. Out of the 15 varieties observed, only four maize varieties namely Kawanda Composite A, Longe 6H, Hybrid 624, Hybrid 6303 were not affected by MLN causing viruses based on absence of symptoms and laboratory confirmation. The presence of MLN on virtually all commonly grown varieties in Uganda suggests high susceptibility. These findings confirm reports by Manje et al. (2015) which revealed the vulnerability of a large array (nearly 90 percent) of pre-commercial and commercial maize germplasm in East Africa to the MLN disease. These maize varieties will need to be tested under known inoculum pressure conditions to determine relative levels of resistance/susceptibility. 
As regards the effect of environmental conditions on MLN incidence, the positive significant correlation coefficients $(\mathrm{P} \leq 0.05)$ between rainfall and MLN disease incidence coupled with a negative significant correlation coefficients $(\mathrm{P} \leq 0.05)$ between altitude and MLN disease incidence indicated that environmental factors directly influenced the development of the disease in maize. Generally over the three cropping seasons, the MLN incidence was favored by maximum temperature range of $22.72-24.64{ }^{\circ} \mathrm{C}$, relative humidity range of $63.22-72.99 \%$ and a rainfall range of $126.62-1723.01 \mathrm{~mm}$. These results seem to suggest that MLN flourishes under narrower temperature ranges and wider rainfall ranges in Uganda which is in agreement with findings in regional study by Isabirye et al. (2016) who reported that MCMV virus has the potential to establish across a wide range of environmental conditions in East Africa. The impact of climate change on environmental conditions such as rainfall, temperature and relative humidity is likely to have an impact on the prevalence of this (MLN disease) and other plant diseases.

\section{Conclusion}

The objective of this study was to establish incidence, severity and distribution of Maize Lethal Necrosis in major maize growing agroecological zones of Uganda. Results showed that MLN was present in 4 of the 5 major maize growing agroecological zones of Uganda but with significantly higher incidence and severity in the Eastern AEZ during the three seasons surveyed. MLN was not widely distributed in Uganda with only 36 (5\%) of the 604 farms surveyed from 16 districts over three seasons confirming the presence of the disease. There was a relationship between the altitude at which maize is grown and MLN incidence suggesting that environmental factors may influence the development of the disease in maize. The predominant MLN causing viruses detected using ELISA were Maize chlorotic mottle virus (MCMV) and Sugarcane mosaic virus (SCMV). However, only MCMV could be confirmed using RT-PCR. MCMV was more prevalent compared to SCMV and could be the key MLN-causal virus driving the MLN epidemic in Uganda. However, given the complexity of MLN epidemiology that involves interaction between host plants and insect vectors, it is necessary to determine the role of other various factors in the spread of the disease in Uganda. Therefore, as maize production in Uganda is increasing, there is a need for development of an area wide MLN disease management strategy to contain the disease. In the interim, efforts should be geared towards increased awareness of MLN disease and deployment of phytosanitary measures to control further spread of the disease among communities where MLN disease has not been reported.

\section{Acknowledgements}

This study was funded by the National Agricultural Research Organization (NARO) of Uganda, through the Agricultural Technology and Agribusiness Advisory Services (ATAAS) Project as part of a PhD research for the first author. We thank District Agricultural Officers especially Mr. Isaac Noel Bwayo and farmers in the target districts for permission to access their fields. Special thanks to National Agricultural Research Laboratories (NARL), Kawanda and International Centre for Tropical Agriculture (CIAT) for permission to access their laboratory facilities and technical personell especially Mr. Allan Male, Mr. Warren Arinaitwe, Mr. Samuel Kiviri and Mr. Stephen Musoke during this study.

\section{References}

Adams, I. P., Harju, V. A., Hodges, T., Hany, U., Skelton, A., Rai, S., ... Boonham, N. (2014). First Report of Maize Lethal Necrosis Disease in Rwanda. New Disease Reports, 29(22), 2044-0588. https://doi.org/ 10.5197/j.2044-0588.2014.029.022

Adams, I. P., Miano, D. W., Kinyua, Z. M., Wangai, A., Kimani, E., Phiri, N., ... Boonham, N. (2013). Use of next-generation sequencing for the identification and characterization of Maize chlorotic mottle virus and Sugarcane mosaic virus causing maize lethal necrosis in Kenya. Plant Pathology, 62, 741-749. https://doi.org/10.1111/j.1365-3059.2012.02690.x

Asea, G. (2013). MLN in Uganda: A disease on the move. Workshop on Maize Lethal Necrosis and its management, February 12-14 ${ }^{\text {th }}$, 2013, Nairobi Safari Club.

Biswanath, D., Jeffers, D., Mahuku, G., Beyene, Y., Makumbi, D., \& Wangai, A. (2013). Standardized Screening protocols for MLN. Workshop on Maize Lethal Necrosis and its management, February 12-14 ${ }^{\text {th }}, 2013$, Nairobi Safari Club.

Brunt, A., Crabtree, K., \& Gibbs, A. (1990). Viruses of tropical plants (p. 707). Wallingford, Oxon, UK: CAB International. 
Cabanas, D. W., Higashi, C. H. V. S., \& Bressan, A. (2013). Dissecting the mode of Maize chlorotic mottle virus transmission (Tombusviridae: Machlomovirus) by Frankliniella williamsi (Thysanoptera: Thripidae). Journal of Economic Entomology, 106, 16-24. https://doi.org/10.1603/EC12056

Clark, M. F., \& Adams, A. N. (1977). Characteristics of the Microplate Method of Enzyme-Linked Immunosorbent Assay for the Detection of Plant Viruses. Journal of General Virology, 34, 475-483. http://doi.org/10.1099/0022-1317-34-3-475

FAOSTAT. (2015). Retrieved April 2, 2016, from http://faostat.fao.org

Ford, R. E., Tosic, M., \& Shukla, D. D. (2004). Maize dwarf mosaic virus. AAB Descriptions of Plant Viruses Online, Description No. 341.

Goldberg, K. B., \& Brakke, M. K. (1987). Concentration of Maize chlorotic mottle virus Increased in Mixed Infections with Maize dwarf mosaic virus, Strain-B. Phytopathology, 77, 162-167. Retrieved from http://digitalcommons.unl.edu/plantpathpapers/177

IPPC. (2014). New Pest of Maize: Maize Lethal Necrosis in Uganda. IPPC Official Pest Report, No. UGA-01/2. Rome, Italy: FAO. Retrieved from https://www.ippc.int

Isabirye, E, B., \& Rwomushana, I. (2016). Current and Future Potential Distribution of Maize chlorotic mottle virus and Risk of Maize Lethal Necrosis Disease in Africa. Journal of Crop Protection, 5(2), 215-228. http://doi.org/10.18869/modares.jcp.5.2.215

Jensen, S. G., Wysong, D. S., Ball, E. M., \& Higley, P. M. (1991). Seed transmission of Maize chlorotic mottle virus. Plant Disease, 75, 497-498. https://doi.org/10.1094/PD-75-0497

Jiang, X. Q., Meinke, L. J., Wright, R. J., Wilkinson, D. R., \& Campbell, J. E. (1992). Maize chlorotic mottle virus In Hawaiian-Grown Maize: Vector Relations, Host Range and Associated Viruses. Crop Protection, 11(3), 248-254. https://doi.org/10.1016/0261-2194(92)90045-7

Kagoda, F., Gidoi, R., \& Isabirye, B. E. (2016). Status of Maize Lethal Necrosis in Eastern Uganda. African Journal of Agricultural Research, 11(8), 652-660. https://doi.org/10.5897/AJAR2015.10616

Kitenge, K. (2012). Current Status of Maize Lethal Necrosis Disease in Tanzania. Paper presented during Regional Workshop on Maize Lethal Necrosis and its Management, Nairobi Safari Club, Kenya.

Lukanda, M., Owati, A., Ogunsanya, P., Valimunzigha, K., Katsongo, K., Ndemere, H., \& Kumar, P. L. (2014). First report of Maize chlorotic mottle virus infecting maize in the Democratic Republic of the Congo. Plant Disease, 98(10), 1448-1449. https://doi.org/10.1094/PDIS-05-14-0484-PDN

Mahuku, G., Lockhart, B. E., Wanjala, B., Jones, M. W., Kimunye, J. N., Stewart, L. R., ... Redinbaugh, M. (2015). Maize Lethal Necrosis (MLN), an Emerging Threat to Maize-Based Food Security in Sub-Saharan Africa. Phytopathology, 105(7), 956-965. https://doi.org/10.1094/PHYTO-12-14-0367-FI

Manje, G., M., Das, B., Makumbi, D., Babu, R., Semagn, K., Mahuku, G., ... Prasanna, B. M. (2015). Genome-Wide Association and Genomic Prediction of Resistance to Maize Lethal Necrosis Disease in Tropical Maize Germplasm. Theoretical and Applied Genetics, 128(10), 1957-1968. https://doi.org/ 10.1007/s00122-015-2559-0

Maule, A. J., \& Wang, D. (1996). Seed transmission of plant viruses: A lesson in biological complexity. Trends in Microbiology, 4(4), 153-158. https://doi.org/10.1016/0966-842X(96)10016-0

Melinda, S., Derek, B., \& Jayne, T. (2013). Maize revolutions in sub-Saharan Africa. An African green revolution (pp. 165-195). Springer Netherlands. https://doi.org/10.1007/978-94-007-5760-8_8

Mikel, M. A., D'Arcy, C. J., \& Ford, R. E. (1984). Seed transmission of Maize dwarf mosaic virus in sweet corn. Journal of Phytopathology, 110(3), 185-191. https://doi.org/10.1111/j.1439-0434.1984.tb00746.x

Nelson, S., Brewbaker, J., \& Hu, J. (2011). Maize chlorotic mottle virus. Plant Disease, 79, 1-6.

Niblett, C. L., \& Claflin, L. E. (1978). Corn lethal necrosis-A new virus disease of corn in Kansas. Plant Disease Reporter, 62(1), 15-19.

Prasanna, B. M. (2014). Maize Lethal Necrosis (MLN) in eastern Africa Tackling a Complex Challenge through Partnerships. AFSTA Conference, March 6, 2014. Tunis, Tunisia.

Scheets, K. (1998). Maize chlorotic mottle machlomovirus and Wheat streak mosaic rymovirus concentrations increase in the synergistic disease corn lethal necrosis. Virology, 242(1), 28-38. https://oi.org/10.1006/ viro.1997.8989 
Uyemoto, J. K., Bockelman, D. L., \& Claflin, L. E. (1980). Severe outbreak of corn lethal necrosis disease in Kansas. Plant Disease, 64(1), 99-100. https://doi.org/10.1094/PD-64-99

Wangai, A. W., Redinbaugh, M. G., Kinyua, Z. M., Miano, D. W., Leley, P. K., Kasina, M., ... Jeffers, D. (2012). First report of Maize chlorotic mottle virus and maize lethal necrosis in Kenya. Plant Disease, 96(10), 1582-1583. https://doi.org/10.1094/PDIS-06-12-0576-PDN

\section{Copyrights}

Copyright for this article is retained by the author(s), with first publication rights granted to the journal.

This is an open-access article distributed under the terms and conditions of the Creative Commons Attribution license (http://creativecommons.org/licenses/by/4.0/). 